\title{
Isolation and Characterization of Haloarchaeal Strain from Puthalam Salt Pan located in the Southern Peninsular Coast of India
}

\author{
Murugan $\mathrm{S}^{1 *}$, Subha $\mathrm{T}^{1}$ and Asha $\mathrm{KRT}^{2}$ \\ Department of Biochemistry, Lakshmipuram College of Arts and Science, India \\ Department of Biochemistry, Govt Arts College, India
}

\begin{abstract}
Halophiles are salt loving organisms that inhabit hypersaline environments. They possess the potential to provide significant opportunities for pharmacology. Moreover, by the concentration of seawater in arid environments, hypersaline environments may easily be created. These facts, along with the presence of novel and stable biomolecules in halophilic bacteria and Archaea, suggest that these microorganisms will prove even more treasured in coming. In the present investigation, water samples were collected from three different sites of Puthalam salt pan. The samples were aseptically transported to the laboratory and subjected to serial dilution using sea water. Among that $10^{-6}$ dilution was taken for the study. 3 different coloured colonies were observed on Zobell marine agar plates, incubated at $37^{\circ} \mathrm{C}$ for 12 days whereas red coloured colony was taken for further study such as biochemical characterization, $\mathrm{pH}$ and temperature optima, halophilicity, growth in the presence of various carbon, $\mathrm{N}_{2}$ as well as inorganic sources and various organic solvents. The observed results indicated that the strain is a red coloured, motile, gram negative rod with evenly spreaded colonies. It shows positive results with catalase, oxidase, gelatin liquefaction, starch hydrolysate, casein production, glucose, sucrose, dextrose and mannitol tests. The isolate shows its well established growth at $\mathrm{pH} 8.8$, temperature $42^{\circ} \mathrm{C}$ and $\mathrm{NaCl}$ of $29 \%$ (excluding the media salinity). It utilizes wide range of carbon, $\mathrm{N}_{2}$ and inorganic sources as well as organic solvents for its growth. The isolate was identified as Halomonas utahensis by $16 \mathrm{~S}$ rRNA sequencing. The nucleotide sequence was submitted to Gen Bank and assigned the accession number KY986725.
\end{abstract}

Keywords: Zobell marine agar; Hypersaline; Halophilicity; Halophiles

\section{Introduction}

An extremophile is an organism that thrives in physiologically orgeochemically extreme conditions that are detrimental to most life on Earth [1]. Most known halophiles are relatively easy to grow, and genera such as Halobacterium, Haloferax, and Haloarcula have become popular models for studies of the archaeal domain as they are much simpler to handle than methanogenic and hyperthermophilic Archaea. Haloarchaea belongs to order halobacteriales and family halobacteriaceae are dominant microorganisms requiring hypersaline environment for their growth. A wide variety of media are used for the cultivation of halophiles and halotolerant bacteria. The media for extreme halophiles have elevated levels of magnesium and the source of water used for preparing hypersaline media varies [2]. Defined media for the extreme halophile, Halosimplex, has broad application [3]. Filtered sea water or salt plains brine were effective bases forgrowing halotolerant Cyanobacteria and algae [4]. Many halophilic and halotolerant microbes isolated to date are neutrophiles, growing best in media with $\mathrm{pH}$ ranging from 6.8 to 7.5 [5]. Alkaliphilic organisms are grown at the $\mathrm{pH}$ range of 8-10 [6]. There is a need and demand for more industrially useful products to the existing ones, so it is important to explore this new habitat which has been particularly abandoned until date [7]. Therefore, in this era researchers are turning their attention towards this less explored and useful kingdom. The southern coast of Kanyakumari harbors a variety of ecosystems for such studies; some of the areas have been already excavated while some are underway. Hence the present investigation deals the isolation, optimization and characterization of haloarchaeal strain from water samples of Puthalam salt pan.

\section{Materials and Methods}

\section{Collection of samples}

Water samples were collected from Puthalam saltpan at 3 different sites. The collected samples were transferred to sterile polythene bags to prevent direct contact with air and are transported to the laboratory in an ice box for further examination. Physico-chemical characterization of water samples were analyzed according to Abbasi, [8].

\section{Isolation and screening of Haloarchaea}

The water samples were serially diluted by taking $1 \mathrm{~mL}$ from each sample individually and a total of ten dilutions $\left(10^{-1}\right.$ to $\left.10^{-10}\right)$ were made by sea water. The $10^{-6}$ dilution is used for plating on Zobell marine agar plates by spread plate method. The plates were incubated at $37^{\circ} \mathrm{C}$ for 12 days [9].

\section{Biochemical characterization}

The culture characterization was identified according to Kamekura et al. [10].

\section{Growth characteristics of isolated strain}

In order to find out growth potential, the broth culture was supplemented with $\mathrm{NaCl}$ of different concentrations $(\mathrm{g} / \mathrm{dL})$ ranging from $25 \%$ to $30 \%$, different temperatures of $37^{\circ} \mathrm{C}$ to $43^{\circ} \mathrm{C}$ and various $\mathrm{pH}$ ranges from 8.0 to 9.2 . The broth cultures were incubated at $37^{\circ} \mathrm{C}$ for 12 days. Growth rate was assessed by recording O.D values at $540 \mathrm{~nm}$. From the O.D values average mean and S.D were calculated.

*Corresponding author: Murugan S, Department of Biochemistry, Lakshmipuram College of Arts and Science, India Tel: 04651223639; E-mail: muruganlpc@gmail.com

Received May 10, 2018; Accepted June 08, 2018; Published June 15, 2018

Citation: Murugan S, Subha T, Asha KRT (2018) Isolation and Characterization of Haloarchaeal Strain from Puthalam Salt Pan located in the Southern Peninsular Coast of India J Microb Biochem Technol 10: 87-95. doi: 10.4172/19485948.1000400

Copyright: () 2018 Murugan S, et al. This is an open-access article distributed under the terms of the Creative Commons Attribution License, which permits unrestricted use, distribution, and reproduction in any medium, provided the original author and source are credited. 
Citation: Murugan S, Subha T, Asha KRT (2018) Isolation and Characterization of Haloarchaeal Strain from Puthalam Salt Pan located in the Southern Peninsular Coast of India J Microb Biochem Technol 10: 87-95. doi: 10.4172/1948-5948.1000400

\section{Determination of growth curve and generation time}

The generation time of isolated strain was determined by inoculating the isolate in marine broth at 0 to 12 days at $37^{\circ} \mathrm{C}$ and kept in rotary shaker at $120 \mathrm{rpm}$. The growth rate was assessed by recording O.D values at $540 \mathrm{~nm}$.

\section{Growth in various organic and inorganic sources}

To find out the efficacy of organic and inorganic sources, the isolated strain was inoculated on Zobell marine agar plates supplemented with various carbon sources such as glucose, fructose, lactose, starch, maltose, galactose and sucrose and $\mathrm{N}_{2}$ sources such as tryptophan, tyrosine, arginine, cysteine, methionine, histidine, glycine and proline in a concentration of $0.1 \mathrm{gm} / \mathrm{dL}(\mathrm{w} / \mathrm{v})$ as well as inorganic sources such as $\mathrm{BaCl}_{2}$, Lead acetate, $\mathrm{MnCl}_{2}$, Mercuric chloride, Nickel sulphate, $\mathrm{CaCl}_{2}$, $\mathrm{FeSO}_{4}, \mathrm{ZnSO}_{4}$, Potassium thiosulphate, $\mathrm{CuSO}_{4}$, Ferrous ammonium sulphate, Sodium sulphate, Lithium carbonate, $\mathrm{MgSO}_{4}$ and $\mathrm{KCl}$ at a concentration of $0.5 \mathrm{gm}(\mathrm{w} / \mathrm{v})$ were used. The plates were incubated at $37^{\circ} \mathrm{C}$ for 12 days. Broth cultures were also prepared with the above sources (except inorganic sources) in different concentrations (glucose: $1-10 \%$, fructose: $1-6 \%$, lactose: $1-5 \%$, starch: $1-11 \%$, maltose: $1-5 \%$, galactose: $1-7 \%$ and sucrose: $1-6 \%$, tryptophan: $0.5-2.0 \%$, tyrosine: $0.5-2 \%$, arginine: $0.2-1.0 \%$, cysteine: $0.5-2.0 \%$, histidine: $0.2-1.2 \%$ and glycine: $0.2-1.0 \%$ ) along with Zobell marine broth. The growth rate of the strain was obtained by recording OD values at $540 \mathrm{~nm}$. Moreover average mean and S.D were calculated

\section{Growth in various organic solvents}

In order to determine the efficacy of organic solvent, the isolated strain was inoculated in Zobell marine agar plates and broth supplemented with different concentrations of organic solvents such as, methanol (1-5\% (v/v)), ethanol (1-7\% (v/ v)), chloroform (1-6\% (v/v)) and diethyl ether $(1-7 \%(\mathrm{v} / \mathrm{v}))$.The results were recorded by calculating average mean and S.D from OD values at $540 \mathrm{~nm}$.

\section{Antimicrobial analysis}

The supernatant liquid collected from the broth was subjected to antimicrobial activity against E.coli, Staphylococcus aureus, Klebsiellasps, Pseudomonas aeroginosa, Enterobacter sp., and Proteus vulgaris by standard paper disc assay method [11].

\section{S rRNA sequencing}

Identification of the isolate was confirmed by $16 \mathrm{~S}$ rRNA sequencing. Genomic DNA of isolate was extracted directly from the colonies grown on solid medium and was used as template for PCR. A single isolated colony was suspended in $10 \mu \mathrm{L}$ of distilled water and heated in a boiling water bath for 2-3 $\mathrm{min}$. The content was centrifuged at $10,000 \mathrm{xg}$ for $3 \mathrm{~min}$ and the supernatant was used as DNA template for PCR system.16S rRNA gene of isolate was amplified using archaeal primers. Forward primer was designed in the laboratory according to Gupta et al. [12] and reverse primer was referred from Xuet et al. [13]. Phylogenetic tree was constructed from evolutionary distances with the help of neighbour-joining method of MEGA 6 program package [14]. The 16S rRNA sequences of the isolated bacterium was submitted to NCBI Gene Bank Database.

\section{Results and Discussion}

\section{Physico-chemical analysis}

The physico-chemical characteristics of water samples are given in Table 1. The average temperature of the sampling sites was $27^{\circ} \mathrm{C}$ at morning and $32^{\circ} \mathrm{C}$ at noon. Colour of the water collected from three sites were observed as reddish pink in site 1, Light pink in site 2 and white in site 3 . Dissolved oxygen content was found to be decreased (2 $\mathrm{mg} / \mathrm{L})$ in water collected from site 3 and was more $(9.02 \mathrm{mg} / \mathrm{mL})$ in site 1. Free $\mathrm{CO}_{2}$ content was found to be $278 \mathrm{ppm}$ at site 1 and $220 \mathrm{ppm}$ at site 2 respectively. The water sample collected nearby the saltpan had a low free $\mathrm{CO}_{2}$ of about $120 \mathrm{ppm}$. Carbonate content of the water sample from site 3 was found to be $10 \mathrm{ppm}$. The bicarbonate content was found to be $60 \mathrm{ppm}, 56 \mathrm{ppm}$ and $54 \mathrm{ppm}$ in site 1, site 2 and site 3 respectively. The present study describes that chloride content of the water sample collected from site 3 was high $(24.82 \mathrm{mg} / \mathrm{L})$, compared to site 1 and 2 . When compared to other water sampling sites, the salinity of the water sample present along seawater (site 1) was found to be $40.78 \mathrm{ppm}$, which was higher than the other samples. The water sample in site 1 had hardness of about $220 \mathrm{mg} / \mathrm{L}$ and it is due to the presence of above said minerals. The conductivity of the water sample nearby the collected salt was found to be 0.08 million/mho. Magnesium content was found to be more $(1.5 \mathrm{~g} / \mathrm{Kg})$ in site 1 comparing to other sites. Nitrogen content of water samples was maximum ( $32 \mathrm{ppm})$ at site 1 , whereas iron content was more at site 2 and site 3 (4.6 and 5 ppm). Copper content was more

\begin{tabular}{|c|c|c|c|}
\hline Characteristics & Sample site 1 & Sample site 2 & Sample site 3 \\
\hline Colour & Reddish pink & Light pink & White \\
\hline Dissolved oxygen $(\mathrm{mg} / \mathrm{mL})$ & 9.02 & 3.54 & 2 \\
\hline Free $\mathrm{CO}_{2}(\mathrm{ppm})$ & 278 & 220 & 120 \\
\hline Carbonate $(\mathrm{ppm})$ & 10 & 24 & 54 \\
\hline Bicarbonate $(\mathrm{ppm})$ & 60 & 56 & 14.50 \\
\hline Chloride $(\mathrm{mg} / \mathrm{L})$ & 24.82 & 20.28 & 26.22 \\
\hline Salinity $(\mathrm{ppm})$ & 40.78 & 36.63 & 800 \\
\hline Hardness $(\mathrm{mg} / \mathrm{L})$ & 220 & 100 & 0.04 \\
\hline Electrical conductivity $(\mathrm{ohm})$ & 0.08 & 8 & 8.3 \\
\hline pH & 8 & 1.09 & 1.05 \\
\hline Magnesium $(\mathrm{g} / \mathrm{L})$ & 1.5 & 24 & 30 \\
\hline Nitrogen $(\mathrm{ppm})$ & 32 & 118 & 110 \\
\hline
\end{tabular}

Table 1: Physicochemical characteristics of solar saltern located at Puthalam near Kanyakumari coast of India. 
Citation: Murugan S, Subha T, Asha KRT (2018) Isolation and Characterization of Haloarchaeal Strain from Puthalam Salt Pan located in the Southern Peninsular Coast of India J Microb Biochem Technol 10: 87-95. doi: 10.4172/1948-5948.1000400

at site $1(1.0 \mathrm{ppm})$ and zinc was found to be more $(0.924 \mathrm{ppm})$ at site 3 . Calcium content was high at site $2(4.3 \mathrm{ppm})$ compared to other sites.

\section{Isolation and screening}

Different shades of red, yellow and white coloured colonies were seen (Figure 1). The observed colonies were sub cultured individually on Zobell marine agar plates. In the present inquest red coloured colonies were used for further analysis. The study based on extremely halophilic Archaea are capable of producing red pigments known as carotenoids which gives red, yellow and orange colour to the organism and also to compact the high salt and intense UV radiation [15]. It was shown that these colored pigments have strong antioxidant, immune boosting activities and protecting premature ageing [16]. Since carotenoids of extremely halophilic Archaea are widely applied in pharmaceutical and medical fields such as antitumour and heart disease prevention agents [17] (Figure 1).

\section{Biochemical characterization of isolate}

The isolated pure culture was subjected to various biochemical characterizations and the results were presented in Table 2 [10]. The results indicate that the strain is red coloured, Gram negative rod with evenly spreaded colonies. It shows motility and positive reaction in catalase, oxidase, gelatin liquefaction, starch hydrolysate, casein production, glucose, sucrose, dextrose, arabinose and mannitol tests. Positive catalase test indicated that some bacteria contain flavoprotein that reduce $\mathrm{O}_{2}$, resulting in the production of $\mathrm{H}_{2} \mathrm{O}_{2}$ or superoxide. These are extremely toxic because they are powerful oxidizing agents and destroy cellular constituents very rapidly. A bacterium must be able to protect itself against such $\mathrm{O}_{2}$ products or it will be killed. Many bacteria possess enzymes that afford protection against toxic $\mathrm{O}_{2}$ products. Add few drops of $\mathrm{H}_{2} \mathrm{O}_{2}$ on bacterial colony bubbles of $\mathrm{O}_{2}$ represent a positive catalase test. Methyl red test showed positive by isolated strain which indicates the bacterium undergoes carbohydrate metabolism leading to the formation of acidic end products like organic acid [18].

\section{Growth characteristics of isolated strain}

The results clearly indicated that the strain exhibited significant growth at $29 \%(\mathrm{w} / \mathrm{v})(0.95 \pm 0.48)$, whereas delayed growth response was observed above $29 \% \mathrm{NaCl}$, as represented in Figure 2. This is because halophiles show more or less wide ranges of growth at different salinities, but experience optimum growth at salinity significantly higher than sea water [19]. Studies on halophilic microorganisms isolated from ponds of China and Karak region showed their optimum growth at the temperature of $35^{\circ} \mathrm{C}$ to $40^{\circ} \mathrm{C}$ [20]. Generally haloarchaea grow best at $37^{\circ} \mathrm{C}$ and others grow below $35^{\circ} \mathrm{C}$ or higher at $40^{\circ} \mathrm{C}$ [21] and optimum growth temperature of $50^{\circ} \mathrm{C}$ have also been reported [22]. In the present investigation the isolated strain shows optimum growth at $42^{\circ} \mathrm{C}$, over that growth was found to be decreased drastically (Figure 3). This might be due to denaturation of proteins responsible for growth at higher temperature.

The strain attained well established growth at $\mathrm{pH} 8.8(0.70 \pm 0.18)$,
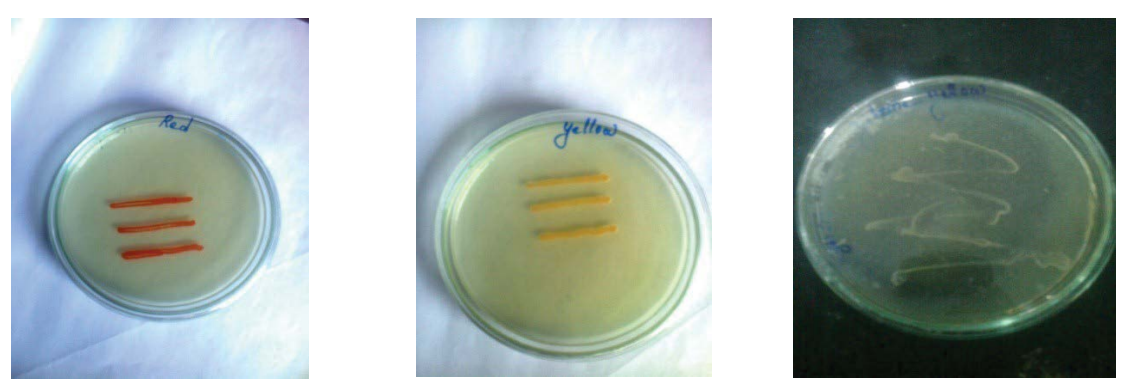

Figure 1: Growth of Haloarchaea on Zobell marine agarplates.

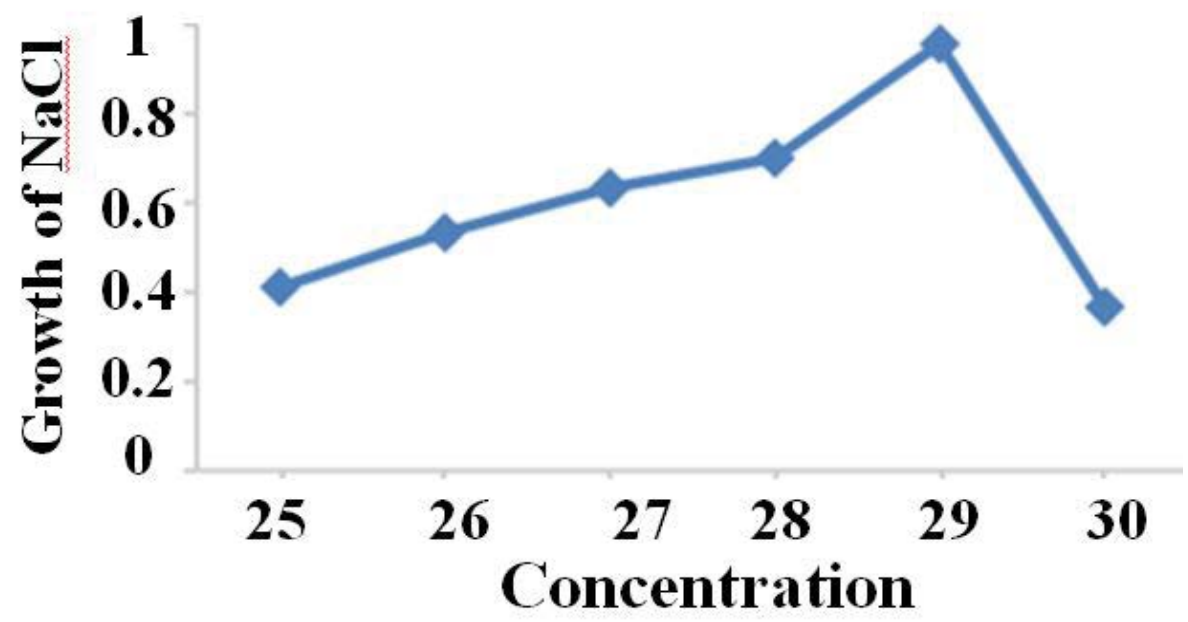

Figure 2: Effect of $\mathrm{NaCl}$ in the growth of isolated strain. 
Citation: Murugan S, Subha T, Asha KRT (2018) Isolation and Characterization of Haloarchaeal Strain from Puthalam Salt Pan located in the Southern Peninsular Coast of India J Microb Biochem Technol 10: 87-95. doi: 10.4172/1948-5948.1000400

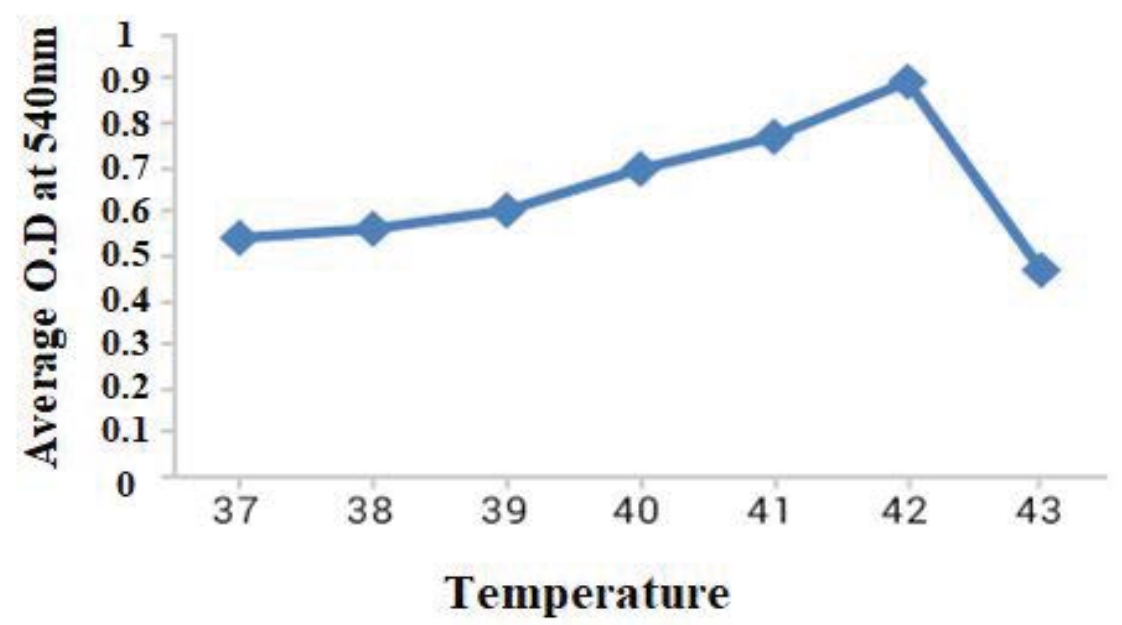

Figure 3: Effect of temperature in growth of isolate.

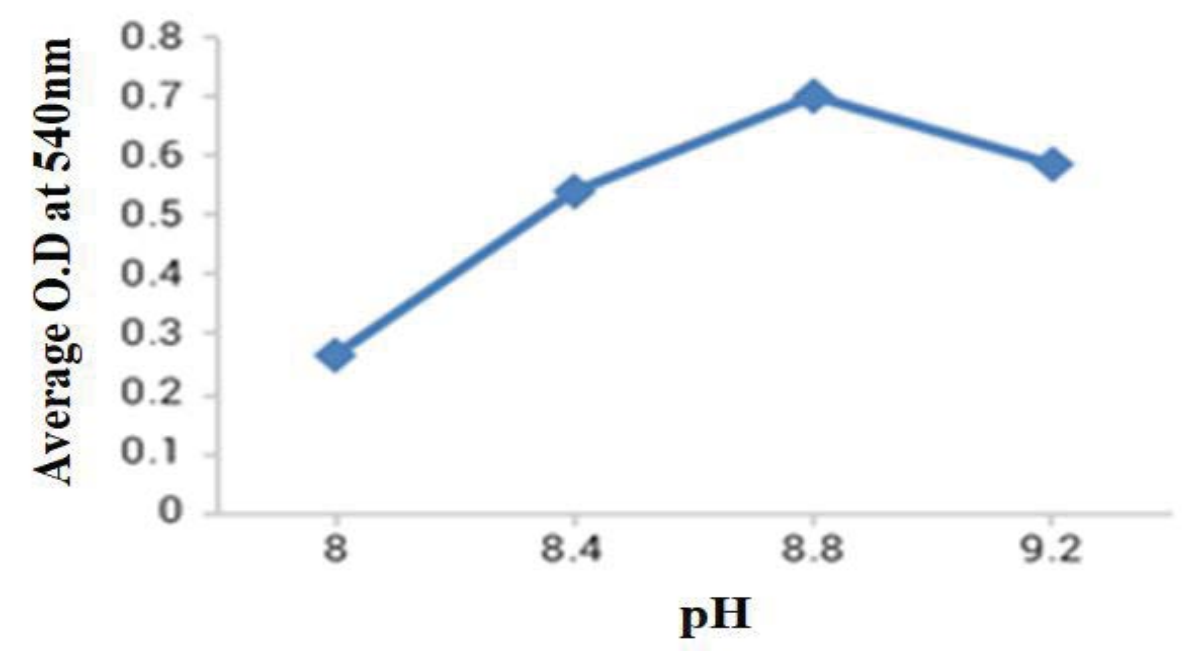

Figure 4: Effect of $\mathrm{pH}$ in the growth of strain.

beyond that the growth rate was found to be decreased substantially as shown in Figure 4. Alkaliphilic organisms are grown well at $\mathrm{pH}$ of 8-10 using $\mathrm{Na}_{2} \mathrm{CO}_{3}$ to maintain the $\mathrm{pH}$ [23]. Mohsinet et al. [24] reported that Halophilic bacterial species grow best at $\mathrm{pH} 7-8$. A novel extreme alkaliphilic isolate named as SAGMI was grown in medium containing optimum $\mathrm{pH}$ of 10 [25].

\section{Growth curve and generation time}

During the growth curve determination, the lag phase occurred in between $1^{\text {st }}$ and $2^{\text {nd }}$ day of inoculation. The onset of log phase was occurred between $3^{\text {rd }}$ and $6^{\text {th }}$ day of inoculation, whereas onset of stationary phase occurred on $6^{\text {th }}$ day up to $9^{\text {th }}$ day and the growth was declined after $9^{\text {th }}$ day as depicted in Figure 5.

\section{Growth in various carbon sources}

The obtained results indicated that high growth rate was occurred in medium containing $10 \%$ starch $(0.98 \pm 0.27)$, followed by $5 \%$ sucrose
$(0.79 \pm 0.17), 9 \%$ glucose $(0.78 \pm 0.24), 6 \%$ galactose $(0.76 \pm 0.13), 4 \%$ lactose $(0.74 \pm 0.13), 5 \%$ fructose $(0.74 \pm 0.18)$ and $4 \%$ maltose $(0.68$ $\pm 0.14)$ respectively. The biomass production increased enormously in medium containing starch and sucrose compared to other sources and control $(0.32 \pm 0.14)$, as represented in Figure 6 .

It was earlier thought that all extremely haloarchaea required a number of amino acids and no carbohydrates for their growth [19]. Halotolerant bacteria have wider metabolic activities so they use many carbon sources for growth [26]. Caton et al. [5] suggested that glucose is the most common carbohydrate added to complex hypersaline media for the growth of haloarcheal species. More over the strain of present work explains that optimum growth of the isolate was reached on $6^{\text {th }}$ day of inoculation beyond that the growth was found to be decreased drastically. This is because halobacteria were considered organisms of very slow growth able to utilize only a stricted range of organic compounds mostly amino acids as energy sources some groups 
Citation: Murugan S, Subha T, Asha KRT (2018) Isolation and Characterization of Haloarchaeal Strain from Puthalam Salt Pan located in the Southern Peninsular Coast of India J Microb Biochem Technol 10: 87-95. doi: 10.4172/1948-5948.1000400

described more recently utilize a wide range of substrates including sugars, and grow more rapidly. Retardation in growth rate may be due to drop in $\mathrm{pH}$ of culture medium because of accumulation of alcohol formed during carbohydrate fermentation. From the results it can be concluded that starch is the best carbon source for the growth of isolated strain. Moreover the obtained results revealed that the strain showed better growth at $2 \%$ tryptophan $(0.85 \pm 0.13), 1.5 \%$ tyrosine $(0.73 \pm 0.10), 0.8 \%$ arginine $(0.76 \pm 0.14), 0.8 \%$ glycine.

$(0.74 \pm 0.13), 1 \%$ histidine $(0.75 \pm 0.11)$ and at $1.5 \%$ cysteine $(0.71 \pm$ 0.09 ) respectively as shown in Figure 7. Comparative analysis indicated that in all the aminoacids, the growth was found to be increased when concentration of aminoacids was increased.

In addition to these, prominent growth was observed in the presence of $\mathrm{MnCl}_{2}, \mathrm{CaCl}_{2}, \mathrm{FeSO}_{4}$, Potassium thiosulphate, $\mathrm{CuSO}_{4}$, Sodium sulphate, Lithium carbonate, $\mathrm{MgSO}_{4}$ and $\mathrm{KCl}$ as presented in Table 3. According to these results it can be concluded that these metal ions are appeared to be essential for the growth of isolated strain. Similar study based on culture media supplemented with metal cations such as $\mathrm{Ca}^{2+}, \mathrm{Mg}^{2+}$ and $\mathrm{Mn}^{2+}$ substantially improved protease production and bacterial biomass of Halobacterium sp. Halobacterium halobium, Pseudomonas salinaria, Pseudomonas cutirubra and Sacinalittoralis failed to grow in the absence of $\mathrm{K}^{+}$. $\mathrm{KCl}$ upto $2 \%$ mimic concentrated sea water [27]. Halotolerant and halophilic organisms grow well in medium supplemented with high concentration of $\mathrm{MgSO}_{4}$ [28].

\section{Effect of organic solvents}

Growth of isolate increased gradually when increasing the concentration of solvents as depicted in Figure 8. Moreover optimum biomass production was found at $4 \%$ methanol $(0.54 \pm 0.17), 6 \%$ diethyl ether $(0.70 \pm 0.22), 6 \%$ ethanol $(0.60 \pm 0.20)$ and $5 \%$ chloroform $(0.63$ $\pm 0.10)$ respectively. Research on solvent tolerance has been detected in many microbes [29] and the mechanism of tolerance has been investigated [30]. Most of the strains were able to grow in hexylether ( $\log$ Pow=5.1), but none of them grow in the presence of n-octane (log Pow=4.9) except Halogeometricum borinquense J CM 10706T and Halorubrum sacchrovorum J CM 8865T. On the other hand, two strains Haloarcula Spp. OHF-1 and 2 exhibited strong tolerance when grown in isooctane (log Pow $=4.8)$. Growth of some strains was retarded in the presence of $n$ - octane, but the final densities were greatly repressed by the presence of solvents [31].

Thus, organic solvent tolerance of halophilic archaea seems to be weaker than that of gram negative bacteria [29]. The present analysis explains that cell densities were found to be greater in the presence of diethylether, compared to other solvents. This suggests that the chromosomes of isolated strain contain genes responsible for organic solvent tolerance.

\section{Antimicrobial assay}

Results were compared with commercially available antibiotic Choremphenicol and are given in Table 4. The isolate shows significant activity against Enterobacter sp., Klebsiella sp., E.coli and Proteus vulgaris

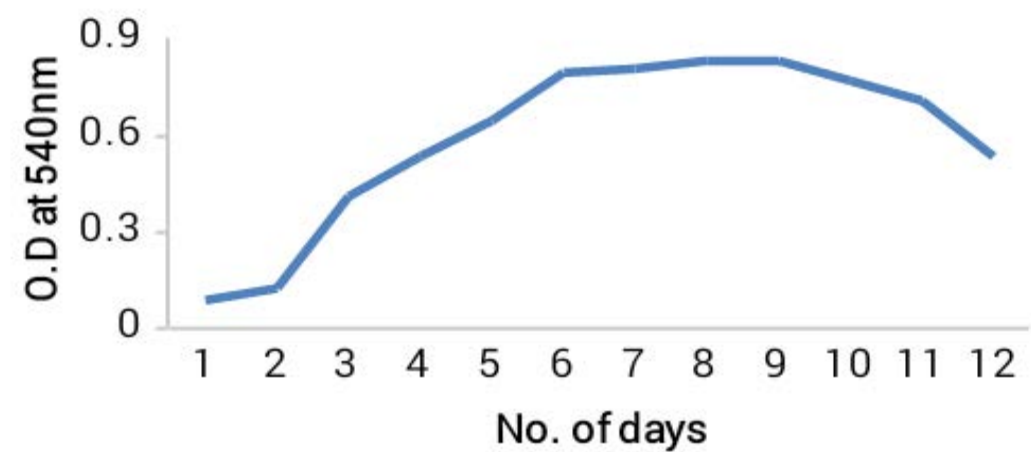

Figure 5: Growth curve of isolated strain.

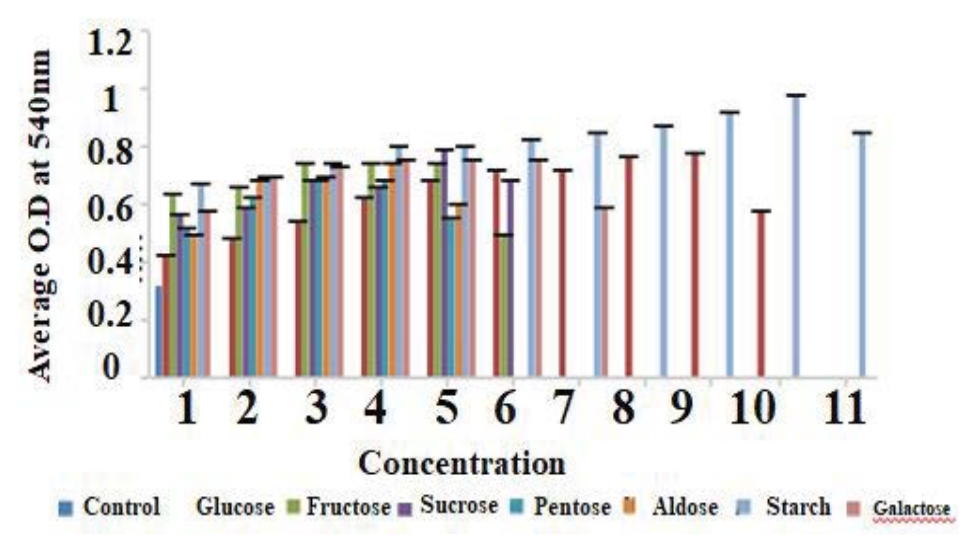

Figure 6: Effect of carbon sources in growth of isolated strain. 
Citation: Murugan S, Subha T, Asha KRT (2018) Isolation and Characterization of Haloarchaeal Strain from Puthalam Salt Pan located in the Southern Peninsular Coast of India J Microb Biochem Technol 10: 87-95. doi: 10.4172/1948-5948.1000400

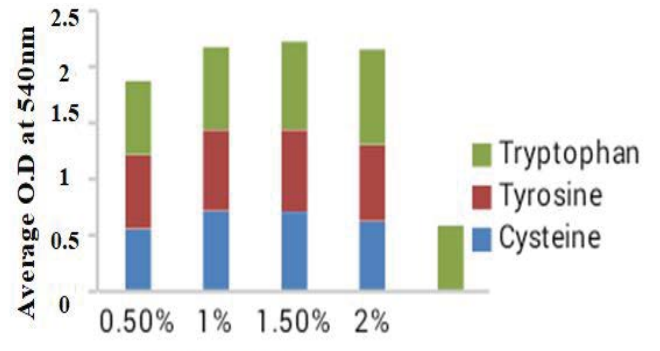

(a)
Concentration

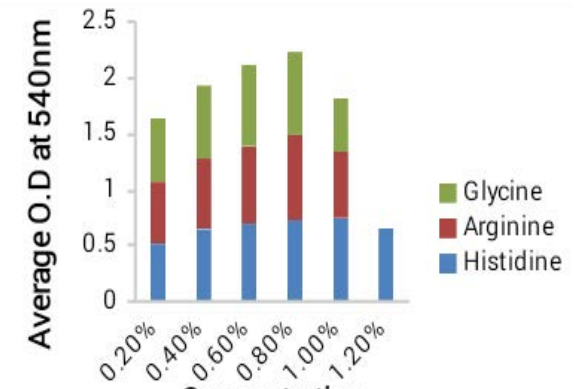

(b)

Concentration

Figure 7: Effect of $\mathrm{N} 2$ sources on growth.

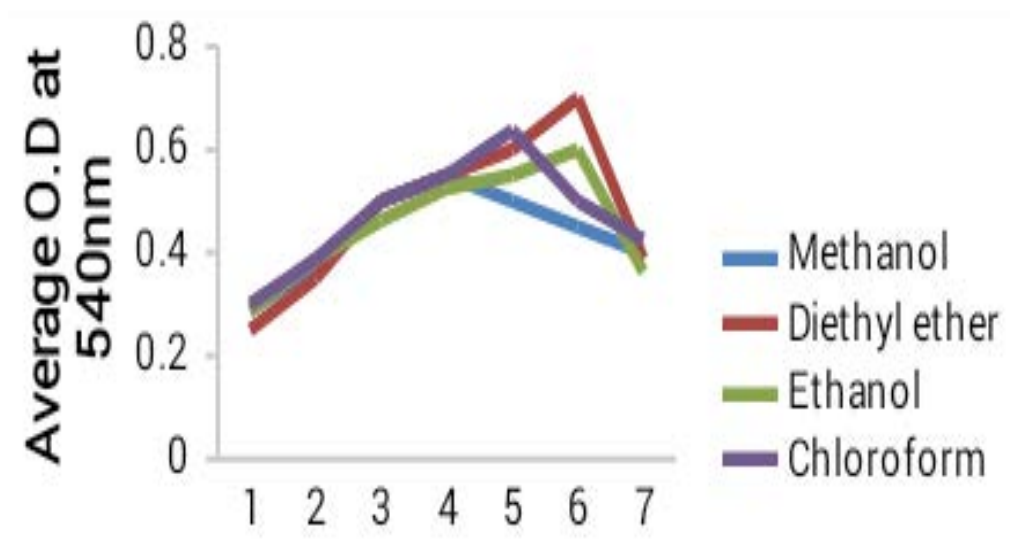

Concentration (\%)

Figure 8: Growth of isolate in different organic solvents.

\begin{tabular}{|c|c|c|}
\hline SI.No & Characteristics & Reaction \\
\hline 1 & Source & Marine water \\
\hline 2 & Colony Morphology on Zobell Marine Agar (ZMA) & Red colour \\
\hline 3 & Gram reaction & $-v e$ \\
\hline 4 & Shape & Rod \\
\hline 5 & Arrangement & Evenly spread \\
\hline 6 & Catalase & + \\
\hline 7 & Oxidase & + \\
\hline 8 & Motility & - \\
\hline 9 & Indole production & - \\
\hline 10 & Methyl red & - \\
\hline 11 & Vogesproscauer test & - \\
\hline 12 & Citrate utilization & - \\
\hline 13 & TSI & - \\
\hline 14 & Urease production & + \\
\hline 15 & Gelatin liquefaction & + \\
\hline 16 & Starch hydrolysate & + \\
\hline 17 & Casein production & + \\
\hline 18 & Glucose & + \\
\hline 19 & Sucrose & + \\
\hline 20 & Dextrose & + \\
\hline 21 & Lactose & + \\
\hline 22 & Arabinose & + \\
\hline 23 & Mannitol & + \\
\hline
\end{tabular}

Table 2: Biochemical characterization of isolated strain. 
Citation: Murugan S, Subha T, Asha KRT (2018) Isolation and Characterization of Haloarchaeal Strain from Puthalam Salt Pan located in the Southern Peninsular Coast of India J Microb Biochem Technol 10: 87-95. doi: 10.4172/1948-5948.1000400

\begin{tabular}{|c|c|c|}
\hline SI. No & Name of the salts & Growth characteristics \\
\hline 1 & Barium chloride & + \\
\hline 2 & Lead acetate & - \\
\hline 3 & Manganous chloride & +++ \\
\hline 4 & Mercuric chloride & - \\
\hline 5 & Nickel sulphate & - \\
\hline 6 & Calcium chloride & +++ \\
\hline 7 & Ferrous sulphate & +++ \\
\hline 8 & Zinc sulphate & - \\
\hline 9 & Potassium thiosulphate & +++ \\
\hline 10 & Coppersulphate & - \\
\hline 11 & Ferrous ammonium sulphate & - \\
\hline 12 & Sodium sulphate & +++ \\
\hline 13 & Lithium carbonate & +++ \\
\hline 14 & Sodium bicarbonate & +++ \\
\hline 15 & Sodium chloride & +++ \\
\hline 16 & Mgnesiumsulphate & +++ \\
\hline 17 & Potassium chloride & +++ \\
\hline
\end{tabular}

Table 3: Effect of inorganic salts in the growth of isolate.

\begin{tabular}{|c|c|c|}
\hline \multirow{2}{*}{ Name of the microorganisms } & \multicolumn{2}{|c|}{ Zone of inhibition (mm) } \\
\cline { 2 - 3 } & Control \\
\hline E.coli & 11 \\
\hline Klebsiella sp. & 10 \\
\hline Pseudomonas aeroginosa & 6 \\
\hline Enterobacter sp. & 10 \\
\hline Proteus vulgaris & 10 \\
\hline
\end{tabular}

Table 4: Antimicrobial activity of isolated strain.

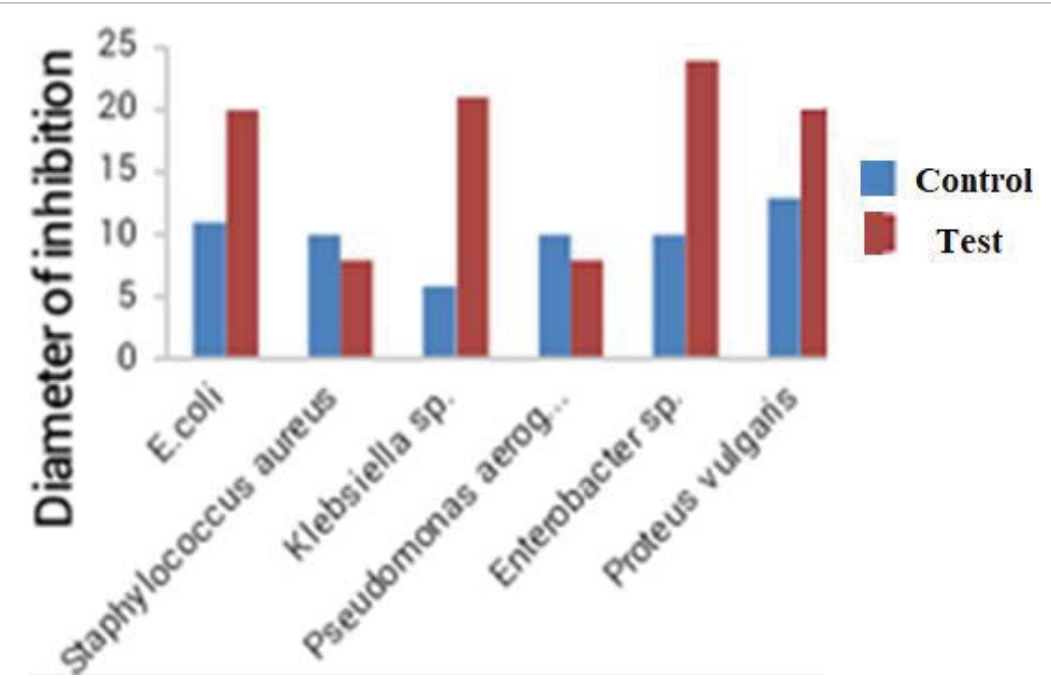

Figure 9: Antimicrobial activity of isolated strain.

and the zone of diameter of inhibition was about $24 \mathrm{~mm}, 21 \mathrm{~mm}, 20$ $\mathrm{mm}$ and $20 \mathrm{~mm}$ respectively. Report on antibacterial activity among marine bacteria is much familiar and has been studied in a number of research works [32,33]. Similar studies on extract of Pseudomonas putida (B151) demonstrated extreme inhibitory effects on S.aureus (26 $\mathrm{mm})$, M. phenylpyruvica $(27 \mathrm{~mm})$, M.luteus $(25 \mathrm{~mm})$ and Rhodovulum species $(28 \mathrm{~mm})$ [34]. Pseudomonas strains are one of the most important groups can able to produce antibiotics. In this investigation, the isolated strain shows significant antimicrobial activity against E.coli (81.8\%), Klebsiella sp. (250\%), Enterobacter sp. (140\%) and Proteus vulgaris (52.8\%).This may be due to the inhibition of cell wall synthesis, accumulation of lysozymes or inhibition of cell multiplication [35]. Based on these observations, it was confirmed that the test organism of the present study was found to produce secondary metabolites against E.coli, Klebsiella sp., Enterobacter sp. and Proteus vulgarisas depicted in Figure 9. Extremophiles are a source of active biomolecules and secondary metabolites [14].

\section{SrRNA sequence analysis}

On the basis of NCBI/ BLAST database the 16S rRNA gene 


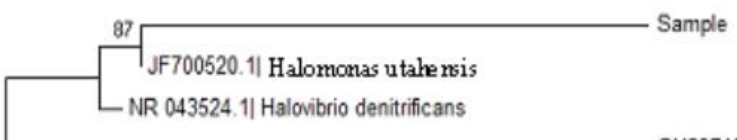

- GU397402.11 Salicola salis

100 DQ087261.1| Salicola marasensis

0.005

Figure 10: Phylogenetic position of isolated strain.

sequence of the isolate showed $99.8 \%$ similarity with Halomonas utahensis SM1. From the results obtained, the test strain belongs to the genus Halomonas. The nucleotide sequence 16S rRNA gene of the strain Halomonas utahensis SM1 was submitted to GenBank and assigned the accession number KY986725 and the constructed phylogenetic tree is shown in Figure 10.

\section{Conclusion}

The strain isolated in the present investigation was identified as Halomonas utahensis SM1 by $16 \mathrm{~S}$ rRNA sequencing. It exhibited well established growth at $\mathrm{pH} 8.8$ and temperature $42^{\circ} \mathrm{C}$. Based on the growth characteristics, the isolated strain can be considered as an "Alkaliphilic moderate thermophile". It utilizes maximum number of carbon as well as nitrogen sources used in this study forits growth. Prominent growth was found to be appeared in plates supplemented with $\mathrm{MnCl}_{2}, \mathrm{CaCl}_{2}, \mathrm{FeSO}_{4}$, Potassium thiosulphate, $\mathrm{CuSO}_{4}$, Sodium sulphate, Lithium carbonate, $\mathrm{MgSO}_{4}$ and $\mathrm{KCl}$. Cell densities were found to be more in broth containing diethyl ether compared to other solvents. Antimicrobial analysis shows that the cell free extract of isolate of present inquest was found to possess significant antimicrobial activity against E.Coli, Klebsiella sp., Enterobacter sp. and Proteus vulgaris. As this microorganism grows in strict conditions of extreme salinity, alkaline $\mathrm{pH}$, high temperature, it has developed a mechanism to compact such harsh environments. Halophiles are natural source of biomolecules; show commercial potential for food, pharmaceutical, biomedical, industrial and environment. It also has decent source of enzymes that can tolerate stringent environmental conditions.

\section{Acknowledgement}

We would like to thank the management of Lakshmipuram College of Arts and Science, Neyyoor, for providing facilities to do this work.

\section{References}

1. Rampelotto $\mathrm{PH}$ (2010) Resistance of microorganisms to extreme environmental conditions and its contribution to Astrology. Sustainability 2: 1602-1623.

2. Bertrand JC, Almallah M, Acquaviva M, Mille, G (1990) Biodegradation of hydrocarbons by an extremely halophilic archaebacterium. Lett Appl Microbiol 11: $19-22$.

3. Vreeland RH, Straight S, Krammes J, Dougherty K, Rosenzweig WD, et al. (2002) Halosimplex carlsbadense gen. nov., sp. nov., a unique halophilicarchaeon with three $16 \mathrm{~S}$ rRNA genes that grows only in defined medium with glycerol acetate orpyruvate. Extremophiles 6: 445-452.

4. Kirwood AE, Henley WJ (2006) Algal community structure and halotolerance as related to the extreme conditions of a terrestrial, hypersaline environment. J Phycol 42: 537-547.

5. Caton TM, Witte LR, Ngyven HD, Buchheim JA, Buchheim MA, et al. (2004) Halotolerant aerobic heterotrophic bacteria from the great salt plains of Okhahma. Microb Ecol 48: 449-462.

6. Soliman GSH, Truper HG (1982) Halobcteriumpharaonissp. nov., a new, extremely haloalkaliphilicarchaebacterium with low magnesium requirement. Zentr Bakteriol Parasite nkInfek Hyg. Abt 13: 318-329.
7. Xuewei X, Min W, Yuehong W, Huibin (2007) Culturablehalophilicarcheal diversity of Ayakakumu salt lake located in Xinijang, China. Acta Ecologica Sinica 27: 3119-3123.

8. Abbasi SA (1998) Water quality sampling analysis. Discovery publishing house, New Delhi.

9. Brown Peterson NJ, Salin, ML (1993) Salt stress in a halophilic bacterium alterations in oxidative metabolism and oxy intermediate scavenging system. $J$ Microbiol 175: 4197-4203.

10. Acar JF (1980) The disc susceptibility test. In: Lorian V, editor. Antibiotics in laboratory medicine. Baltimore, MD: Williams and Wilkins: 24-54.

11. Gupta R, Lanter JM, Woese CR (1983) Sequence of the 16 S ribosomal RNA from Halobacterium volcanii. An archaebacterium Science 221: 656- 659.

12. Xu XW, Liu SJ, Tohty D, Oren A, Wu M, et al. (2005) Haloterrigena saccharevitans sp. nov., $\mathrm{n}$ extremely halophilicarchean from Xin-J iang, China. Int Syst Evol Microbiol 55: 2539-2542.

13. Kanekar PP, Sarnaik SS, Kelkar AS (2012) Screening of Alkaliphilic Haloalkaliphilic bacteria and alkalithermophilicActinomycetes isolated from alkaline Soda Lake of Lonar, India forantimicrobial activity. Int J Pharm Bio Sci 85: 258-274.

14. Kamekura M, Dyall Smith ML (1995) Taxonomy of the family Halobacteriaceae and the description of two new genera Halobrobacterium and Natrialba. J Gen Appl Microbiol 41: 333-350.

15. Oren A (2013) Salinibacter: An extremely halophilic bacterium with archaeal properties. FEMS Microbiol Lett 342: 1-9.

16. Gammone MA, Riccioni G, D'Orazio N (2015) Marine carotenoids against oxidative stress: Effects on human health. Mar Drugs 13: 6226-6246.

17. Alvarado C, Alvarez $P, J$ imenz $L$ (2005) Improvement of leukocyte functions in young prematurely aging mice after a 5 -week ingestion of a diet supplemented with biscuits enriched in antioxidants. Antioxid Redox Signal 7: 1203-1210.

18. Anilkumar HS, Vdlapudikumar Vidyavathi N (2014) Optimization of fermentation parameters and enzyme immobilization of alpha-galactosidase isolated from different bacteria. Int J Curr Microbiol App Sci 3: 154-167.

19. Asha K, Vinitha D, Kiran S, Manjusha W, Sukumaran N, et al. (2004) Isolation and cultivation of halophilicarchaea from solar saltern located in Peninsular coast of India. Inter J Microbiol 1: 20-29.

20. Joo WA, Kim CW (2005) Proteomics of halophilicarchaea. J chromatogr B analyt Technol Biomed life Sci 815: 237-250.

21. Torreblanca M, Rodriguez-Valera F, Juez G, Ventosa A, Kamekura M, et al (1986) Classification of non alkalipilichalo bacteria based on composition and description of liquid composition and description of haloarcula gen. nov. and Haloferaxgen. nov. Syst. Appl Microbiol 8: 89-99.

22. Mesbah NM, Hedrick DB, Peacock AD, Rohde M, Wiegel J (2007) Natranaerobiusthermophilus gen. nov., sp. nov., a halophilicalkalithermophilic bacterium from soda lakes of the Wadi An Natrun, Egypt and proposal of Natranaerobiaceae fam. nov.and Natranaerobiales ord. nov. Int J Syst Evol Microbial 57: 2507-2512.

23. Pikuta EV, Hoover RB, Bej AK, Marsic D, Detkova EN, et al. (2003) Tindalliacaliforniensis sp. nov., a new anerobic, haloalkaliphilic, spore forming acetogen isolated from Mono Lake in California. Extremophiles 7: 327-334.

24. Mohsin A, Veena U, Neha C, Devendra Singh R (2014) Isolatioon and biochemical characterisation of Halophiles from Sahastradhara region, Debradum, India. 
Citation: Murugan S, Subha T, Asha KRT (2018) Isolation and Characterization of Haloarchaeal Strain from Puthalam Salt Pan located in the Southern Peninsular Coast of India J Microb Biochem Technol 10: 87-95. doi: 10.4172/1948-5948.1000400

25. Takai K, Moser PD, Onstott CT, Spoelstra N, Pfifner MS, et al. (2001) Alkaliphilustransvaalensis gen. nov., sp. nov., an extremely alkaliphilic bacterium isolated from a deep south African gold mine. Intl J Syst Evol Microbiol 51:1245-1256.

26. Litzner BR, Caton TM, Schneegurt MA (2006) Carbon substrate utilization, antimicrobial sensitivity and numerical taxonomy of bacterial isolates from the great salt plains of Oklahoma. Arch Microbiol 185: 286-296.

27. Caton TM, Caton IR, Witte LR, Schneegurt MA (2009) Archaeal diversity at the great salt plains of Oklahoma described by cultivation and molecular analyses. Microb Ecol 58: 519-528.

28. Crisler JD, New ville TM, Chen F, Clark BC, Schneegurt MA (2012) Bacterial growth at the high concentrations of Magnesium sulfate found in Martian soils. Astrobiology 12: 98-106.

29. Inoue A, Horikoshi K (1991) Estimation of solvent tolerance of bacteria by the solvent parameter log P. J Ferment Bioeng 71: 194-196.
30. Kobayashi H, Takami H, Hirayama H, Kobata K, Usami R, et al. (1999) Outer membrane changes in a toluene sensitive mutant of toluene tolerant Pseudomonas putida IH-2000. J Bacteriol 181: 4493-4498.

31. Ron U, Tadamasa F, Toru M, Akira I, Yasuhiko Y, et al. (2003) Organic solvent tolerance of Halophilic Archaea. Biosci Biotechnol Biochem 67: 1809-1812.

32. Isnansetyo A, Kamei Y (2003) Pseudomonas phenolica sp.nov., a novel marine bacterium that produces phenolic antimethicillin-resistant Staphylocccusaureus substances. Int J Syst Evol Microbiol 53: 583-588.

33. Uzair B (2006) A newantibacterial compound produced by indigenous marine bacteria; fermentation, isolation and biological activity. Nat Pro Res 20: 1326-1331.

34. Ying XU, Xian C, Xiang X, Pei Yuan Q (2007) Antibacterial and antilarval activity of deep-sea bacteria from sediments of the west Pacific Ocean. J Bioadhes Biofilm Res 23: 131-137.

35. Cucco M, Guasco B, Malacarne G, Ottonelli R (2007) Effect of $\beta$-carotene on adult immune condition and antibacterial activity of eggs of Grey partridge Perdixperdix. Com Biochem Physiol 147: 1038- 1046. 